\title{
Konsumsi Zat Gizi pada Balita Stunting dan Non-Stunting di Kabupaten Bangkalan
}

\section{Nutrients Consumption of Stunted and Non-Stunted Children in Bangkalan}

\author{
Ulul Azmy*, Luki Mundiastuti ${ }^{1}$
}

\begin{abstract}
ABSTRAK
Latar Belakang : Makanan yang dikonsumsi anak usia balita menentukan pertumbuhan dan perkembangan di masa yang akan datang. Kurangnya konsumsi zat gizi dapat menyebabkan beberapa masalah gizi, salah satunya yaitu stunting.

Tujuan : Penelitian ini bertujuan menganalisis konsumsi zat gizi pada balita stunting dan non-stunting usia 24 - 59 bulan di Kabupaten Bangkalan.

Metode : Jenis penelitian ini adalah observasional dengan desain case control. Penelitian dilaksanakan di desa Banyuajuh dan desa Kramat Kabupaten Bangkalan. Sampel pada penelitian ini berjumlah 48 balita yang berusia antara $24-59$ bulan dan dipilih secara acak. Pengumpulan data dilakukan dengan menggunakan metode recall selama 3 hari.

Hasil : Sebagian besar balita stunting memiliki tingkat konsumsi energi, lemak, protein, karbohidrat, seng, dan zat besi pada kategori kurang. Sedangkan pada balita non-stunting sebagian besar memiliki tingkat konsumsi zat gizi yang cukup. Terdapat hubungan status gizi dengan asupan energi $(p=0,015$; $\mathrm{OR}=4,048)$, protein $(p=0,012 ; \mathrm{OR}=1,6)$, lemak $(p=0,002 ; \mathrm{OR}=1,7)$, karbohidrat $(p=0,014 ; \mathrm{OR}=$ $1,7)$, seng $(p=0,026 ; O R=1,7)$, dan tidak ada hubungan zat besi $(p=0,066)$ dengan status gizi.

Kesimpulan : Balita non-stunting memiliki tingkat konsumsi zat gizi yang lebih baik dibandingkan dengan balita stunting. Terdapat hubungan antara asupan energi, protein, lemak, karbohidrat, dan seng dengan status gizi (TB/U), dan tidak ada hubungan antara asupan zat besi dengan status gizi (TB/U).
\end{abstract}

Kata kunci: balita, konsumsi zat gizi, stunting

\section{ABSTRACT}

Background : Foods consumed by under five children determine their growth and development in the future. The lack of nutrient intake can lead to several nutritional problems, including stunting.

Objectives: This research aimed to analyze nutrient consumption of stunted and non-stunted children aged 24 - 59 month in Bangkalan.

Methods: This was an observational study with case-control design, conducted in Banyuajuh, Kramat, and Pejagan sub-district in Bangkalan district. The research sample consist of 48 children aged 24 - 59 month selected through simple random sampling. Data were collected using three-times food recall $24 \mathrm{H}$ non-consecutive days.

Results: Majority of stunting children have low levels energy, fat, protein, carbohydrate, zinc and iron intake. While non-stunted chidren, have adequate nutrients intake. There was significant correlation between nutritional status $(H / A)$ with intake of total energy $(p=0.015 ; O R=4.048)$, protein $(p=$ $0.012 ; O R=1.6)$, fat $(p=0.002 ; O R=1.7)$, carbohydrate $(p=0.014 ; O R=1.7)$, and zinc $(p=0.026 ; O R$ $=1.7)$. But, none in iron consumption $(p=0.066)$. 
Conclusions : The results showed that non-stunted children have better nutrients intake compare to the stunted children. Moreover the results also showed significant correlation between consumption of total energy, protein, fat, carbohydrate, and zinc with nutritional status (HAZ), but not significantly corelated with iron intake.

Keywords: children , nutrient intake, stunting

*Koresponden:

azmyulul91@gmail.com

${ }^{1}$ Akademi Gizi Surabaya, Jawa Timur, Indonesia

\section{PENDAHULUAN}

Balita merupakan masa penting pertumbuhan anak. Asupan zat gizi melalui makanan dan hidup sehat pada periode ini akan menentukan pertumbuhan dan perkembangan di masa yang akan datang ${ }^{1}$. Kurangnya asupan zat gizi dapat menyebabkan beberapa masalah gizi, salah satunya yaitu stunting. Stunting adalah kurangnya energi protein jangka panjang yang ditandai kurangnya tinggi badan menurut umur ${ }^{2}$. Indonesia masih memiliki masalah stunting dengan prevalensi sebesar $36,4 \%$. Indonesia merupakan negara tertinggi ke 4 untuk angka stunting di Asia ${ }^{3}$. Di Provinsi Jawa Timur prevalensi balita stunting sebesar $26,7 \%$ dari total populasi balita di Provinsi Jawa Timur ${ }^{4}$. Salah satu wilayah Kabupaten yang memiliki angka prevalensi stunting yang cukup tinggi yaitu Kabupaten Bangkalan. Berdasarkan data Pemantauan Status Gizi (PSG) Direktorat Gizi Masyarakat tahun 2017, prevalensi balita stunting di Kabupaten Bangkalan sebesar $43 \%{ }^{4}$.

Untuk mendukung pertumbuhan dan perkembangan balita, pemilihan jenis makanan menjadi sangat penting untuk memenuhi kebutuhan zat gizi. Secara umum terdapat 6 zat gizi yang dibutuhkan oleh tubuh yaitu karbohidrat, lemak, protein, vitamin, mineral seperti diantaranya zat besi (Fe) dan seng $(Z n)^{5}$. Karbohidrat dalam tubuh manusia bermanfaat sebagai sumber energi utama yang diperlukan untuk beraktivitas, karbohidrat yang berlebihan dalam tubuh akan disimpan dalam bentuk lemak sebagai cadangan sumber energi. Lemak dalam tubuh bermanfaat sebagai sumber energi dan melarutkan vitamin sehingga dapat mudah diserap oleh usus. Protein merupakan zat yang membantu untuk membangun sel tubuh sehingga sangat penting bagi balita yang berada dalam tahap pertumbuhan dan perkembangan. Selain itu protein berfungsi sebagai pengganti sel tubuh yang rusak. Mineral dan vitamin merupakan zat gizi yang diperlukan dalam proses pertumbuhan dan perkembangan balita $^{5}$. Hal tersebut menunjukkan pentingnya asupan nutrisi yang adekuat, berdasarkan penelitian sebelumnya menyatakan bahwa semakin rendah konsumsi zat gizi pada balita, maka semakin berisiko mengalami stunting ${ }^{6}$

Untuk melihat hubungan asupan zat gizi dengan status gizi stunting pada balita usia 24 - 59 bulan, dilakukan penelitian yang dilaksanakan di Kabupaten Bangkalan sebagai salah satu wilayah yang memiliki prevalensi stunting yang tinggi.

\section{METODE}

Jenis penelitian ini adalah observasional dengan desain case control. Sampel dalam penelitian ini adalah balita usia $24-59$ bulan. Penelitian dilaksanakan di Desa Banyuajuh, Desa Kramat, dan Desa Pejagan Kabupaten Bangkalan pada bulan Mei - Juni 2018. Dalam menentukan jumlah sampel pada penelitian ini, menggunakan rumus Lemeshow (1990) dengan nilai $p=43 \%$ yaitu prevalensi balita stunting di Kabupaten menurut Direktorat Gizi Masyarakat tahun 2018 sehingga diperoleh sampel minimal sebanyak 24 balita untuk masing-masing kelompok. Pengambilan sampel menggunakan teknik simple random sampling dari total 29 balita stunting di 3 desa tersebut yang sesuai dengan kriteria inklusi. Kriteria inklusi yaitu balita yang memiliki status Z-Score > -3 SD sampai < -2 SD dan berusia $24-59$ bulan yang berada di 3 desa 
tersebut. Sedangkan kriteria ekslusi yaitu balita yang menderita penyakit serius atau terdapat kelainan bawaan. Variabel independen dalam penelitian ini adalah asupan zat gizi dan variabel dependen adalah status gizi (TB/U) balita usia $24-59$ bulan.

Pengumpulan data dilakukan dengan meggunakan metode wawancara untuk mengetahui karakteristik orang tua seperti pendidikan yang dikategorikan dalam tinggi (SMA, perguruan tinggi) dan rendah (tidak tamat SD, SD, SMP), pekerjaan, dan total pendapatan rumah tangga berdasarkan UMK. Selain itu dilakukan recall selama 3 hari berselang satu hari. Tinggi badan pada balita diukur dengan menggunakan microtoise dengan tingkat ketelitian 0,1. Dari hasil pengukuran tinggi badan, kemudian status gizi ditentukan menggunakan aplikasi WHO Anthro Plus. Data dianalisis dengan menggunakan Uji Pearso untuk menganalisis hubungan status gizi dengan asupan zat gizi.

\section{HASIL DAN PEMBAHASAN}

\section{Karakteristik Keluarga Subyek Penelitian}

Berdasarkan Tabel 1. Pada kondisi stunting ditemukan sebanyak $50 \%$ balita berjenis kelamin laki-laki dan 50\% perempuan. Sedangkan pada balita dengan kondisi nonstunting menunjukkan $62,5 \%$ sampel dengan jenis kelamin perempuan. Pada sampel yang mengalami stunting ditemukan sebanyak $62,5 \%$ berada pada usia $48-60$ bulan. Tingkat pendidikan kepala keluarga sebagian besar memiliki latar belakang pendidikan tinggi yaitu sebanyak $62,5 \%$ ditemukan pada sampel dengan kondisi stunting, sedangkan pada sampel dengan kondisi non-stunting lebih tinggi untuk jumlah kepala keluarga yang berlatar belakang pendidikan tinggi yaitu $91,7 \%$. Pada pendidikan ibu yang memiliki latar belakang pendidikan tinggi yaitu sebesar $54,2 \% \%$ pada balita stunting dan $75 \%$ pada balita non-stunting. Menurut Khan (2007), adanya malnutrisi disebabkan beberapa akar masalah salah satunya adalah masalah pendidikan ${ }^{11}$. Tingkat pendidikan ayah dikaitkan dengan meningkatnya pendapatan sehingga meningkatkan daya beli makanan. Tingginya tingkat pendidikan seseorang juga mempengaruhi bagaimana pola hidup dan tingkah laku dari seseorang serta juga mempengaruhi tingkat kemampuan individu dalam menyerap informasi yang didapatkan ${ }^{12}$. Namun tingkat pendidikan bukan satu-satunya faktor yang menyebabkan balita mengalami masalah gizi, pengetahuan tentang asupan dan makanan yang baik bisa diperoleh dari berbagai sumber yang ada seperti bidan, petugas kesehatan, kader, bahkan melalui media masa yang menyajikan berbagai informasi sehingga tidak selalu dari bangku pendidikan formal ${ }^{13}$.

Sebesar 95,8\% kepala keluarga memiliki pekerjaan, sedangkan pada status pekerjaan ibu menunjukkan bahwa lebih banyak ibu yang bekerja pada balita dengan kondisi nonstunting yaitu sebesar $37,5 \%$ sedangkan pada balita dengan kondisi stunting sebesar $16,7 \%$.

Tabel 1. Distribusi Karakteristik Responden

\begin{tabular}{lcccc}
\hline \multirow{2}{*}{ Variabel } & \multicolumn{2}{c}{ Kasus } & \multicolumn{2}{c}{ Kontrol } \\
\cline { 2 - 5 } & $\mathbf{n}$ & $\%$ & $\mathbf{n}$ & $\%$ \\
\hline Jenis Kelamin & & & & \\
$\quad$ Laki-laki & 12 & 50 & 9 & 37,5 \\
$\quad$ Perempuan & 12 & 50 & 15 & 62,5 \\
Usia & & & & \\
$\quad 2-3$ tahun & 9 & 37,5 & 12 & 50 \\
$\quad 4-5$ tahun & 15 & 62,5 & 12 & 50 \\
$\quad \begin{array}{l}\text { Pendidikan Kepala } \\
\text { Keluarga }\end{array}$ & & & & \\
$\quad$ Pendidikan & 9 & 37,5 & 2 & 8,3 \\
$\quad$ Rendah & & & & \\
$\quad$ Pendidikan Tinggi & 15 & 62,5 & 22 & 91,7 \\
Pendidikan Ibu & & & & \\
$\quad$ Pendidikan & 11 & 45,8 & 6 & 25 \\
$\quad$ Rendah & & & & \\
$\quad$ Pendidikan Tinggi & 13 & 54,2 & 18 & 75 \\
$\begin{array}{l}\text { Pekerjaan Kepala } \\
\text { Keluarga }\end{array}$ & & & & \\
$\quad$ Bekerja & & & & \\
$\quad$ Tidak Bekerja & 1 & 4,2 & 1 & 4,2 \\
Status Pekerjaan & & & & \\
Ibu & & & & \\
$\quad$ Bekerja & 4 & 16,7 & 9 & 37,5 \\
$\quad$ Tidak Bekerja & 20 & 83,3 & 15 & 62,5 \\
$\begin{array}{l}\text { Pendapatan } \\
\text { (Sesuai UMK) }\end{array}$ & & & & \\
$\quad$ <Rp. 1.663.975 & 6 & 25 & 1 & 4,2 \\
$\geq$ Rp. 1.663.975 & 18 & 75 & 23 & 95,8 \\
\hline
\end{tabular}


Tabel 2. Kecukupan Konsumsi Zat Gizi Berdasarkan AKG dan Hubungan Asupan Zat Gizi dengan Status Gizi (TB/U)

\begin{tabular}{|c|c|c|c|c|c|}
\hline \multirow{2}{*}{ Zat Gizi } & \multirow{2}{*}{$\begin{array}{c}\text { Kecukupan } \\
\text { dan Konsumsi } \\
\text { Zat Gizi } \\
\end{array}$} & \multicolumn{2}{|c|}{ Status Gizi } & \multirow{2}{*}{$\begin{array}{c}\text { OR } \\
(95 \% \mathrm{Cl})\end{array}$} & \multirow{2}{*}{ p-value } \\
\hline & & Kasus & Kontrol & & \\
\hline \multirow{3}{*}{ Energi } & Kurang & $17(70,8 \%)$ & $9(37,5 \%)$ & \multirow{3}{*}{$\begin{array}{c}4,048 \\
(1,21-13,53)\end{array}$} & \multirow{3}{*}{$0,015^{*}$} \\
\hline & Cukup & $7(29,2 \%)$ & $15(62,5 \%)$ & & \\
\hline & Rata-rata & $568,93 \pm 1280,13$ & $300,8 \pm 2469,3$ & & \\
\hline \multirow{3}{*}{ Protein } & Kurang & $6(25 \%)$ & $4(16,7 \%)$ & \multirow{3}{*}{$\begin{array}{c}1,6 \\
(0,4-6,87)\end{array}$} & \multirow{3}{*}{$0,012 *$} \\
\hline & Cukup & $18(75 \%)$ & $20(83,3 \%)$ & & \\
\hline & Rata-rata & $23,63 \pm 53,83$ & $11,9 \pm 93,7$ & & \\
\hline \multirow{3}{*}{ Lemak } & Kurang & 12 (50\%) & $9(37,5 \%)$ & \multirow{3}{*}{$\begin{array}{c}1,7 \\
(0,52-5,26)\end{array}$} & \multirow{3}{*}{$0,002^{*}$} \\
\hline & Cukup & $12(50 \%)$ & $15(62,5 \%)$ & & \\
\hline & Rata-rata & $18,3 \pm 59,37$ & $11,7 \pm 104,2$ & & \\
\hline \multirow{3}{*}{ Karbohidrat } & Kurang & $16(66,7 \%)$ & $13(54,2 \%)$ & \multirow{3}{*}{$\begin{array}{c}1,7 \\
(0,52-5,44)\end{array}$} & \multirow{3}{*}{$0,014^{*}$} \\
\hline & Cukup & $8(33,3 \%)$ & $11(45,8 \%)$ & & \\
\hline & Rata-rata & $54,17 \pm 171$ & $40,3 \pm 291,4$ & & \\
\hline \multirow{3}{*}{ Seng } & Kurang & $11(45,8 \%)$ & $8(33,3 \%)$ & \multirow{4}{*}{$\begin{array}{c}1,7 \\
(0,52-5,44)\end{array}$} & \multirow{3}{*}{$0,026^{*}$} \\
\hline & Cukup & $13(54,2 \%)$ & $16(66,7 \%)$ & & \\
\hline & Rata-rata & $2,4 \pm 8,03$ & $0,8 \pm 13$ & & \\
\hline & Kurang & $20(83,3 \%)$ & $15(62,5 \%)$ & & \\
\hline \multirow[t]{2}{*}{ Zat Besi } & Cukup & $4(16,7 \%)$ & $9(37,5 \%)$ & \multirow[t]{2}{*}{ 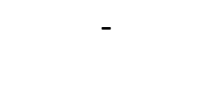 } & \multirow[t]{2}{*}{0,066} \\
\hline & Rata-rata & $2,4 \pm 15,53$ & $1,1 \pm 24,1$ & & \\
\hline
\end{tabular}

Keterangan : *Signifikan berdasarkan Pearson test correlation dengan $\alpha=5 \%$

Untuk kategori pendapatan disesuaikan dengan Upah Minimum Kabupaten Bangkalan (UMK) yaitu sebesar Rp. 1.663.975. Pada balita dengan kondisi stunting, keluarga yang memiliki pendapatan diatas UMK sebesar $75 \%$ sedangkan pada balita dengan kondisi nonstunting, yang memiliki pendapatan diatas UMK yaitu sebesar $95,8 \%$.

Berdasarkan pendapatan yang dimiliki oleh keluarga dapat mencerminkan tingkat kemampuan keluarga tersebut dalam konsumsi makanan sehari-hari. Adanya permasalahan gizi yang mempengaruhi tumbuh kembang anak disebabkan karena adanya krisis ekonomi dari keluarga yang erat kaitannya dengan pendapatan yang diterima dari keluarga tersebut. Sebagian besar anak balita yang mengalami gangguan pertumbuhan memiliki status ekonomi relatif rendah $^{14}$. Hasil Riskesdas tahun 2013 menunjukkan bahwa adanya kejadian stunting pada balita paling banyak disebabkan karena tingkat pendapatan dan pendidikan orang tua yang rendah. Menurut UNICEF, rendahnya status ekonomi dari sebuah keluarga dianggap memiliki dampak pada pertumbuhan anak. Rendahnya status ekonomi keluarga berdampak pada kemungkinan anak menjadi kurus dan pendek ${ }^{15}$. Rendahnya status ekonomi keluarga yang menyebabkan anak menjadi kurus dan pendek dapat dipengaruhi oleh rendahnya akses kesehatan dan pangan yang diperoleh. Selain itu menurut Bishwakarma (2011), keluarga dengan tingkat pendapatan yang tinggi akan lebih mudah mendapatkan akses pendidikan dan kesehatan sehingga status gizi anak bisa lebih baik ${ }^{16}$. Selain itu keterbatasan penghasilan keluarga dapat mempengaruhi kualitas makanan keluarga baik kualitas maupun jumlah ${ }^{17}$.

\section{Asupan Zat Gizi Balita}

Berdasarkan Tabel 2, kecukupan zat gizi energi untuk kategori kurang pada balita stunting lebih tinggi yaitu sebesar $70,8 \%$ sedangkan pada balita non-stunting sebagian besar pada kecukupan energi kategori cukup dengan nilai rata-rata konsumsi tertinggi sebesar 2469,3 kkal. Semakin kurang konsumsi energi maka berisiko 4,048 kali lebih 
besar mengalami stunting. Dari Tabel 3 menunjukkan bahwa rata-rata tertinggi asupan energi pada balita non-stunting lebih tinggi yaitu sebesar 2469,3 kkal. Selain itu nilai $p$ dari asupan energi terhadap status gizi adalah 0,015 , sehingga hasil menunjukkan bahwa terdapat hubungan yang bermakna antara asupan energi dengan status gizi (TB/U). Hal ini menunjukkan bahwa semakin baik asupan energi pada balita, maka semakin normal pula status gizinya. Penelitian ini sejalan dengan penelitian yang dilakukan oleh Nagari, et al (2017) dimana terdapat hubungan antara tingkat konsumsi energi dengan status gizi pada anak ${ }^{18}$. Energi dalam tubuh manusia timbul karena adanya pembakaran dari karbohidrat, protein, dan lemak. Oleh karena itu, dibutuhkan adanya zat makanan yang dapat mencukupi kebutuhan tubuh dari seseorang tersebut ${ }^{19}$. Hal ini menunjukkan bahwa semakin baik konsumsi energi pada balita maka semakin baik status gizinya. Berdasarkan penelitian yang dilakukan Oktarina et al (2013) menunjukkan bahwa balita yang memiliki asupan energi rendah berisiko stunting.

Berdasarkan Tabel 2 menunjukkan bahwa konsumsi zat gizi makro seperti protein, lemak, dan karbohidrat sebagian besar balita stunting memiliki tingkat kecukupan kurang. Sedangkan pada balita non-stunting sebagian besar pada tingkat kecukupan yang cukup. Dari Tabel 2 diketahui bahwa protein, lemak, dan karbohidrat berhubungan dengan status gizi (TB/U). Semakin kurang konsumsi protein maka berisiko 1,6 kali lebih besar untuk mengalami stunting. Penelitian sejalan dengan penelitian yang dilakukan oleh Sulistianingsih, et al (2015) yang menunjukkan bahwa terdapat hubungan antara asupan protein dengan status gizi (TB/U) pada balita. Balita yang kekurangan protein memiliki risiko 17,5 kali menderita stunting jika dibandingkan dengan balita yang memiliki asupan protein yang cukup $^{20}$. Protein memiliki pengaruh yang sangat penting terhadap pertumbuhan balita, secara umum fungsi protein untuk pertumbuhan, pembentukan komponen struktural, dan pembentukan antibodi ${ }^{21}$. Selain protein, lemak berhubungan dengan status gizi TB/U dikarenakan dalam lemak terkandung asam lemak esensial yang memiliki peran dalam mengatur kesehatan ${ }^{22}$. Selain itu simpanan energi dapat berasal dari konsumsi lemak dan lemak sebagai alat pengangkut dan pelarut vitamin larut lemak dalam tubuh dimana fungsi-fungsi tersebut sangat mempengaruhi pertumbuhan balita ${ }^{5}$. Dari hasil penelitian menunjukkan semakin kurang konsumsi lemak maka berisiko 1,7 kali lebih besar mengalami stunting.

Selain itu penelitian ini sejalan dengan penelitian yang dilakukan oleh Sari, et al (2016) pada anak balita di Desa Nelayan Puger Wetan, Kecamatan Puger, Kabupaten Jember yang menunjukkan bahwa terdapat hubungan yang bermakna antara tingkat konsumsi karbohidrat dengan status gizi berdasarkan indeks $\mathrm{TB} / \mathrm{U}^{23}$. Banyak sekali fungsi karbohidrat diantaranya sebagai penyuplai energi otak dan syaraf, pengatur metabolisme, dan karbohidrat merupakan zat gizi utama yang menyuplai energi untuk tubuh supaya dapat melakukan aktivitasnya. Karbohidrat sangat dibutuhkan pada setiap daur kehidupan untuk menghasilkan energi, begitu pula dengan masa balita dimana tingkat aktivitas bermain yang tinggi dan membutuhkan energi untuk perkembangan otak $^{24}$. Semakin kurang konsumsi karbohidrat maka berisiko 1,7 kali lebih besar mengalami stunting.

Berdasarkan Tabel 2 menunjukkan bahwa kecukupan konsumsi zink pada balita non-stunting dengan kategori cukup lebih tinggi bila dibandingkan dengan balita stunting. Rata-rata tertinggi asupan seng pada balita non-stunting sebesar $13 \mathrm{mg}$, angka tersebut lebih tinggi dari angka rata-rata asupan seng tertinggi pada balita stunting. Selain zat gizi makro, terdapat hubungan yang bermakna antara asupan seng dengan status gizi (TB/U). Penelitian ini sejalan dengan penelitian yang dilakukan Dewi dan Nindya (2017) yang menyatakan terdapat hubungan yang signifikan antara konsumsi seng dengan kejadian stunting ${ }^{25}$. Seng berperan dalam pertumbuhan balita karena peran seng dalam metabolisme asam nukleat dan sintesis protein. Selain itu seng juga memiliki peran dalam pertumbuhan sel, replika sel, dan 
kekebalan tubuh $^{26}$. Seng dikaitkan dengan salah satu faktor pertmbuhan, oleh karena itu seng sangat dibutuhkan pada masa-masa pertumbuhan seperti pada masa balita. Salah satu masalah gizi yang disebabkan karena kekurangan konsumsi seng adalah stunting ${ }^{27}$.

Sedangkan asupan zat besi sama-sama menunjukkan kecukupan konsumsi zat gizi dengan kategori cukup lebih tinggi pada balita non-stunting, dengan rata-rata asupan tertinggi pada balita non-stunting sebesar 24,1 mg. Dari Tabel 2 terlihat bahwa tidak terdapat hubungan yang bermakna asupan zat besi dengan status gizi (TB/U). Penelitian ini tidak sejalan dengan penelitian yang dilakukan oleh Sulistianingsih, et al (2015) yang menyatakan bahwa terdapat hubungan antara asupan besi dengan kejadian stunting pada balita. Hasil penelitian dari Sulistianingsih, et al (2015) menyatakan bahwa balita yang kurang asupan besi berisiko menderita stunting ${ }^{20}$. Zat besi dikaitkan sebagai salah satu mineral yang berperan dalam pertumbuhan balita karena salah fungsinya untuk kekebalan tubuh ${ }^{26}$. Pada masa balita sangat rentan terhadap terjadinya penyakit yang akan menyebabkan masalah gizi, oleh karena itu beberapa konsumsi mineral dibutuhkan untuk mempertahankan kekebalan tubuh. Hasil penelitian menunjukkan bahwa status gizi tidak hanya dipengaruhi oleh konsumsi zat besi saja namun zat gizi lainnya.

\section{KESIMPULAN}

Hasil penelitian menunjukkan sebagian besar balita stunting memiliki tingkat konsumsi zat gizi (energi, lemak, protein, karbohidrat, seng, dan zat besi) pada kategori rendah. Sedangkan pada balita non-stunting sebagian besar pada tingkat konsumsi zat gizi yang cukup. Terdapat hubungan asupan energi, protein, lemak, karbohidrat, dan seng pada balita dengan status gizi (TB/U), sehingga dibutuhkan asupan zat gizi yang adekuat selama masa balita. Sedangkan pada tingkat konsumsi zat besi tidak berhubungan secara bermakna dengan status gizi (TB/U).

\section{ACKNOWLEDGEMENT}

Ucapan terimakasih penulis berikan kepada Badan Kesatuan Bangsa dan Politik Provinsi Jawa Timur dan Kabupaten Bangkalan, Dinas Ketahanan Pangan dan Dinas Kesehatan yang telah memberikan izin dan membantu kelancaran sebelum dan selama penelitian dan dosen pembimbing atas pengajaran, bimbingan, dan arahan yang diberikan.

\section{REFERENSI}

1. Brown, J. E. Nutrition Through the Life Cycle. (Cengage Learning, 2011).

2. Whitney, E. \& Rolfes, S. R. Understanding Nutrition. (Thomson Learning, 2008).

3. WHO. World health statistics 2016: Monitoring Health for the SDGs, Sustainable Development Goals. (WHO Press, 2016).

4. Direktorat Gizi Masyarakat. Hasil Pemantauan Status Gizi (PSG) Tahun 2017. (Kementerian Kesehatan Republik Indonesia, 2018).

5. Andriani, M. \& Wirjatmadi, B. Peranan Gizi dalam Siklus Kehidupan. (Kencana Prenadamedia Group, 2014).

6. Oktarina, Z. \& Sudiarti, D. T. FAKTOR RISIKO STUNTING PADA BALITA (24-59 BULAN) DI SUMATERA (Risk Factors of Stunting among Children [24-59 months] in Sumatera). (2013).

7. Madanijah, S., Zulaikhah \& Br. Munthe, Y. Sumbangan Konsumsi Ikan dan Makanan Jajanan Terhadap Kecukupan Gizi Anak Balita pada Keluarga Nelayan Buruh dan Nelayan Juragan. Media Gizi dan Kel. 30 (1), 31-41 (2006).

8. Kranz, S., Jones, N. R. V \& Monsivais, P. Intake Levels of Fish in the UK Paediatric Population. Nutrients 9, 1-10 (2017).

9. $M, M . \& K, M$. Contribution of Fish Consumption to Reduction of Malnutrition among the Under-Five Children in Salima, Malawi. iMedPub Journals 2, 1-5 (2017). 
10. World Bank. Nutritional Failure in Ecuador Causes, Consequences, and Solutions. (The World Bank Press, 2007).

11. Hidayati, L., Hadi, H. \& Kumara, A. Kekurangan Energi dan Zat Gizi Merupakan Faktor Risiko Kejadian Stunted Pada Anak Usia 1-3 Tahun yang Tinggal Di Wilayah Kumuh Perkotaan Surakarta. J. Kesehat. 3, 89-104 (2010).

12. Nasikhah, R. \& Margawati, A. Faktor Risiko Kejadian Stunting Pada Balita Usia 24 - 36 Bulan Di Kecamatan Semarang Timur. J. Nutr. Coll. 1, 176184 (2012).

13. Marelda, A. R. Hubungan Tingkat Pendapatan Keluarga, Pendidikan dan Pengetahuan Dengan Status Gizi Pada Balita Di Desa Parit Baru Kabupaten Kubu Raya Kalimantan Barat Tahun 2014. J. Proners 1, (2014).

14. Aridiyah, F. O., Rohmawati, N. \& Ririanty, M. Faktor-faktor yang Mempengaruhi Kejadian Stunting pada Anak Balita di Wilayah Pedesaan dan Perkotaan. e-Jurnal Pustaka Kesehat. 3, (2015).

15. UNICEF. Improving child nutrition: The achievable imperative for global progress. Division of Communication, UNICEF (2013). doi:978-92-806-4686-3

16. Bishwakarma, R. Spatial Inequality in Child Nutrition in Nepal : Implications of Regional Context and Individual/Household Composition. (University of Maryland, 2011).

17. Khotimah, H. \& Kuswandi, K. Hubungan Karakteristik Ibu Dengan Status Gizi Balita Di Desa Sumur Bandung Kecamatan Cikulur Kabupaten Lebak Tahun 2013. J. Obs. Sci. 2, 146-162 (2014).

18. Nagari, R. K. \& Nindya, T. S. Tingkat Kecukupan Energi, Protein Dan Status Ketahanan Pangan Rumah Tangga Berhubungan Dengan Status Gizi Anak Usia 6-8 Tahun. Amerta Nutr 1, 189-197 (2017).

19. Muchlis, N., Hadju, V. \& Jafar, N. Hubungan Asupan Energi dan Protein Dengan Status Gizi Balita Di Kelurahan
Tamamaung. 1-8 (2007).

20. Sulistianingsih, A. \& Yanti, D. A. M. Kurangnya Asupan Makan Sebagai Penyebab Kejadian Balita Pendek ( Stunting ). Dunia Kesehat. 5, 71-75 (2013).

21. Damayanti, D. Ilmu Gizi Teori dan Aplikasi. (EGC, 2017).

22. Susetyowati. Ilmu Gizi Teori dan Aplikas. (EGC, 2017).

23. Sari, I. Y., Ningtyias, F. W. \& Rohmawati, N. Konsumsi Makanan dan Status Gizi Anak Balita ( 24 - 59 bulan ) di Desa Nelayan Puger Wetan Kecamatan Puger Kabupaten Jember. Artik. IIm. Has. Penelit. Mhs. (2016).

24. Panel, E. \& Nda, A. Scientific Opinion on nutrient requirements and dietary intakes of infants and young children in the European Union. EFSA J. 11, 1-103 (2013).

25. Dewi, E. K. \& Nindya, T. S. Hubungan Tingkat Kecukupan Zat Besi Dan Seng Dengan Kejadian Stunting Pada Balita 623 Bulan. Amerta Nutr 1, 361-368 (2017).

26. Adriani, M. \& Wirjatmadi, B. Gizi dan Kesehatan Balita. (Kencana Prenadamedia Group, 2014).

27. Hotz, C. \& Brown, K. H. International zinc consultative group: Technical Brief Document \#1. Assessment of the Risk of Zinc Deficiency in Populations and Options for Its Control. Food Nutr. Bull. 25, no 1, S99-203 (2004).

28. Sidiq, A. Uji Kadar Protein Organoleptik Pada Telur Ayam Lenghorn Setelah Disuntik Dengan Ekstra Black Garlic. Naskah Publ. Univ. Muhammadiyah Surakarta (2014).

29. Hafiludin. Analisis Kandungan Gizi Pada Ikan Bandeng yang Berasal Dari Habitat yang Berbeda. J. Kelaut. 8, 37-43 (2015).

30. Mulyaningsih, T. R. Kandungan Unsur Fe dan Zn Dalam Bahan Pangan Produk Pertanian, Peternakan, dan Perikanan Dengan Metode KO-AANI. J. Sains dan Teknol. Nukl. Indones. X, 71-80 (9AD). 